\title{
1 Supplement of
}

$2 \quad \mathbf{2 1}^{\text {st }}$ Century Asian air pollution impacts glacier in northwestern 3 Tibet

4 M. Roxana Sierra-Hernández ${ }^{1}$, Emilie Beaudon ${ }^{1}$, Paolo Gabrielli ${ }^{1,2}$, and Lonnie G. Thompson ${ }^{1,2}$

$6 \quad{ }^{1}$ Byrd Polar and Climate Research Center, The Ohio State University, Columbus, OH, 43210, USA

$7 \quad{ }^{2}$ School of Earth Sciences, The Ohio State University, Columbus, OH, 43210, USA

8 Correspondence to: M. Roxana Sierra-Hernández (sierra-hernandez.1@ osu.edu) 
Table S1. Limit of detection (LOD), procedural blank (TE concentrations of the water used to make the artificial ice

45 core and of the ice from the artificial ice core), accuracy, and blanks average. LOD corresponds to three times the

46 standard deviation of the concentration of 10 measurements of ultrapure water $(18.3 \mathrm{M} \Omega$ ). The concentrations of the

47 Reference Material (TMRain-95) are reported as total concentrations accounting for the dilution factor of $\sim 20$.

48

\begin{tabular}{|c|c|c|c|c|c|}
\hline \multirow[b]{2}{*}{$\begin{array}{c}\text { Trace } \\
\text { Element }\end{array}$} & \multirow[b]{2}{*}{ LOD } & \multicolumn{2}{|c|}{ Procedural Blank } & \multicolumn{2}{|c|}{ Accuracy } \\
\hline & & $\begin{array}{c}\text { Ultrapure } \\
\text { water }\end{array}$ & $\begin{array}{c}\text { Artificial } \\
\text { ice core }\end{array}$ & $\begin{array}{c}\text { TMRain-95 } \\
\text { Found }\end{array}$ & $\begin{array}{c}\text { TMRain-95 } \\
\text { Certified } \\
\end{array}$ \\
\hline $\mathrm{Ag}\left(\mathrm{pg} \mathrm{g}^{-1}\right)$ & 0.1 & $0.5 \pm 0.1$ & $1 \pm 0.01$ & & \\
\hline $\mathrm{Al}\left(\mathrm{ng} \mathrm{g}^{-1}\right)$ & 0.03 & $0.6 \pm 0.6$ & $0.9 \pm 1.2$ & $2 \pm 0.9$ & $2 \pm 0.9$ \\
\hline As $\left(\mathrm{pg} \mathrm{g}^{-1}\right)$ & 0.8 & $3 \pm 0.7$ & $4 \pm 1$ & $1126 \pm 153$ & $1070 \pm 250$ \\
\hline $\mathrm{Ba}\left(\mathrm{pg} \mathrm{g}^{-1}\right)$ & 2 & $27 \pm 11$ & $32 \pm 19$ & $762 \pm 59$ & $730 \pm 150$ \\
\hline $\mathrm{Bi}\left(\mathrm{pg} \mathrm{g}^{-1}\right)$ & 0.01 & $0.03 \pm 0$ & $0.04 \pm 0.03$ & $802 \pm 13$ & $630 \pm 260$ \\
\hline $\mathrm{Cd}\left(\mathrm{pg} \mathrm{g}^{-1}\right)$ & 0.1 & $0.9 \pm 0.5$ & $1 \pm 0.2$ & $468 \pm 14$ & $480 \pm 120$ \\
\hline $\operatorname{Co}\left(\operatorname{pg~g}^{-1}\right)$ & 0.2 & $0.3 \pm 0.1$ & $1 \pm 0.5$ & $227 \pm 10$ & $220 \pm 37$ \\
\hline $\mathrm{Cr}\left(\mathrm{pg} \mathrm{g}^{-1}\right)$ & 1 & $3 \pm 3$ & $7 \pm 5$ & $770 \pm 37$ & $790 \pm 170$ \\
\hline Cs $\left(\mathrm{pg} \mathrm{g}^{-1}\right)$ & 0.1 & $1 \pm 0.3$ & $2 \pm 0.5$ & & \\
\hline $\mathrm{Cu}\left(\mathrm{pg} \mathrm{g}^{-1}\right)$ & 1 & $21 \pm 4$ & $27 \pm 5$ & $6305 \pm 101$ & $6200 \pm 930$ \\
\hline $\mathrm{Fe}\left(\mathrm{ng} \mathrm{g}^{-1}\right)$ & 0.2 & $0.1 \pm 0.2$ & $0.4 \pm 0.3$ & $24 \pm 10$ & $24 \pm 4$ \\
\hline $\mathrm{Ga}\left(\mathrm{pg} \mathrm{g}^{-1}\right)$ & 0.5 & $2 \pm 2$ & $3 \pm 3$ & & \\
\hline $\mathrm{Li}\left(\mathrm{ng} \mathrm{g}^{-1}\right)$ & 0.04 & $0.8 \pm 0.3$ & $0.7 \pm 0.1$ & $0.3 \pm 0.2$ & $0.4 \pm 0.08$ \\
\hline $\operatorname{Mg}\left(\mathrm{ng} \mathrm{g}^{-1}\right)$ & 0.02 & $0.2 \pm 0.1$ & $0.2 \pm 0.1$ & & \\
\hline $\operatorname{Mn}\left(\operatorname{pg~g}^{-1}\right)$ & 1 & $4 \pm 5$ & $5 \pm 2$ & $6013 \pm 77$ & $6100 \pm 780$ \\
\hline $\operatorname{Mo}\left(\mathrm{pg} \mathrm{g}^{-1}\right)$ & 0.2 & $0.5 \pm 0.2$ & $1 \pm 0.1$ & $174 \pm 7$ & $170 \pm 100$ \\
\hline $\mathrm{Na}\left(\mathrm{ng} \mathrm{g}^{-1}\right)$ & 0.4 & $1 \pm 0.7$ & $2 \pm 0.7$ & & \\
\hline $\mathrm{Nb}\left(\mathrm{pg} \mathrm{g}^{-1}\right)$ & 0.2 & $5 \pm 2$ & $10 \pm 6$ & & \\
\hline $\mathrm{Ni}\left(\mathrm{pg} \mathrm{g}^{-1}\right)$ & 0.8 & $3 \pm 0.6$ & $3 \pm 0.8$ & $845 \pm 35$ & $800 \pm 170$ \\
\hline $\mathrm{Pb}\left(\mathrm{pg} \mathrm{g}^{-1}\right)$ & 0.3 & $0.43 \pm 0.2$ & $0.8 \pm 0.5$ & $281 \pm 5$ & $290 \pm 93$ \\
\hline $\mathrm{Rb}\left(\mathrm{pg} \mathrm{g}^{-1}\right)$ & 1 & $18 \pm 18$ & $25 \pm 16$ & & \\
\hline $\mathrm{Sb}\left(\mathrm{pg} \mathrm{g}^{-1}\right)$ & 0.1 & $0.1 \pm 0.03$ & $0.1 \pm 0.01$ & $322 \pm 7$ & $350 \pm 100$ \\
\hline Sn $\left(\mathrm{pg} \mathrm{g}^{-1}\right)$ & 4 & $2 \pm 0.5$ & $2 \pm 0.7$ & & \\
\hline $\operatorname{Sr}\left(\mathrm{pg} \mathrm{g}^{-1}\right)$ & 5 & $285 \pm 133$ & $296 \pm 132$ & $1729 \pm 58$ & $1700 \pm 260$ \\
\hline $\operatorname{Ti}\left(\mathrm{pg} \mathrm{g}^{-1}\right)$ & 10 & $21 \pm 26$ & $31 \pm 24$ & & \\
\hline $\mathrm{Tl}\left(\mathrm{pg} \mathrm{g}^{-1}\right)$ & 0.02 & $0.03 \pm 0.01$ & $0.05 \pm 0.02$ & $330 \pm 6$ & $330 \pm 72$ \\
\hline $\mathrm{U}\left(\mathrm{pg} \mathrm{g}^{-1}\right)$ & 0.03 & $0.07 \pm 0.01$ & $0.09 \pm 0.02$ & $262 \pm 5$ & $250 \pm 60$ \\
\hline $\mathrm{V}\left(\mathrm{pg} \mathrm{g}^{-1}\right)$ & 1 & $4 \pm 4$ & $7 \pm 5$ & $678 \pm 39$ & $640 \pm 120$ \\
\hline $\mathrm{Zn}\left(\mathrm{pg} \mathrm{g}^{-1}\right)$ & 3 & $8 \pm 4$ & $5 \pm 1$ & & \\
\hline
\end{tabular}

50

51

52 
53 Table S2. Loadings and communalities of each Trace Element (TE) of the first three factors for the entire

54 concentration data set (1971-2015).

\begin{tabular}{ccccc}
\hline TE & Factor 1 & Factor 2 & Factor 3 & Communality \\
\hline $\mathrm{Ag}$ & 0.92 & -0.29 & 0.16 & 0.95 \\
$\mathrm{Al}$ & 0.96 & -0.24 & 0.07 & 0.99 \\
$\mathrm{As}$ & 0.83 & -0.50 & 0.02 & 0.94 \\
$\mathrm{Ba}$ & 0.85 & -0.47 & 0.07 & 0.96 \\
$\mathrm{Bi}$ & 0.94 & -0.25 & 0.15 & 0.97 \\
$\mathrm{Cd}$ & 0.79 & -0.30 & 0.50 & 0.97 \\
$\mathrm{Co}$ & 0.96 & -0.26 & 0.08 & 0.99 \\
$\mathrm{Cr}$ & 0.96 & -0.26 & 0.08 & 0.99 \\
$\mathrm{Cs}$ & 0.95 & -0.25 & -0.02 & 0.97 \\
$\mathrm{Cu}$ & 0.93 & -0.32 & 0.10 & 0.98 \\
$\mathrm{Fe}$ & 0.96 & -0.25 & 0.06 & 0.99 \\
$\mathrm{Ga}$ & 0.96 & -0.26 & 0.06 & 0.99 \\
$\mathrm{Li}$ & 0.79 & -0.56 & 0.01 & 0.95 \\
$\mathrm{Mg}$ & 0.80 & -0.57 & 0.05 & 0.96 \\
$\mathrm{Mn}$ & 0.84 & -0.43 & 0.18 & 0.92 \\
$\mathrm{Mo}$ & 0.41 & -0.85 & 0.08 & 0.90 \\
$\mathrm{Na}$ & 0.09 & -0.96 & 0.03 & 0.93 \\
$\mathrm{Nb}$ & 0.94 & -0.28 & -0.02 & 0.96 \\
$\mathrm{Ni}$ & 0.95 & -0.28 & 0.10 & 0.99 \\
$\mathrm{~Pb}$ & 0.93 & -0.24 & 0.24 & 0.97 \\
$\mathrm{Rb}$ & 0.94 & -0.32 & -0.01 & 0.99 \\
$\mathrm{Sb}$ & 0.78 & -0.57 & 0.04 & 0.93 \\
$\mathrm{Sn}$ & 0.82 & -0.36 & 0.30 & 0.89 \\
$\mathrm{Sr}$ & 0.20 & -0.95 & 0.07 & 0.94 \\
$\mathrm{Ti}$ & 0.79 & -0.58 & 0.04 & 0.96 \\
$\mathrm{Tl}$ & 0.92 & -0.35 & 0.11 & 0.98 \\
$\mathrm{U}$ & 0.82 & -0.50 & 0.08 & 0.93 \\
$\mathrm{~V}$ & 0.95 & -0.29 & 0.07 & 0.99 \\
$\mathrm{Zn}$ & 0.94 & -0.24 & 0.21 & 0.99 \\
\hline Variance $(\%)$ & 72.6 & 21.4 & 2.1 & \\
Variance $(\%)$ & 72.6 & 94.0 & 96.1 & \\
\hline & & & &
\end{tabular}

56

57

58 
In Thompson et al. (2018), we showed the high reproducibility between the 1992 and 2015 Guliya $\delta^{18} \mathrm{O}$ profiles. This reproducibility is also observed in the TE records (Figure S1). Likewise, the $\mathrm{Al}$ and $\mathrm{Fe}$ (not shown) median concentrations are $0.3 \mu \mathrm{g} \mathrm{g}^{-1}$ in both records during the 1971-1991 period in which both TE records overlap.

Figure S1 displays 5-year median concentrations and EFs of the 1992 (1650-1991) and 2015 (1971-2015) cores for TEs that showed post-1850s enrichments ( $\mathrm{Pb}, \mathrm{Cd}, \mathrm{Zn}$, and $\mathrm{Al}$ for comparison). The 5-year median concentrations of $\mathrm{Cd}, \mathrm{Pb}$, and $\mathrm{Zn}$ are slightly higher in the 2015 record than the 1992 time series for the 1971-1991 period. For example, the $\mathrm{Cd}$ median concentrations are 5 and $6 \mathrm{pg} \mathrm{g}^{-1}$ in the 1992 and 2015 records, respectively. The difference in concentrations between the 1992 and the 2015 records is not significant (Mann-Whitney test: $\mathrm{p}<0.0005$ for medians) and may be due to spatial variability of ice layers between the two boreholes. Similarly, during the 1971-1991 period, the EFs in the 2015 record are slightly higher than in the 1992 record. This might result from the natural signal to noise ratio differences between the two records. Despite the slight EF differences between the two records during the 1971-1991 period, the reproducibility of TEs allows determination of temporal trends from pre-industrial times ( 1650) into the $21^{\text {st }}$ century (2015) using the 1992 and the 2015 TE records.
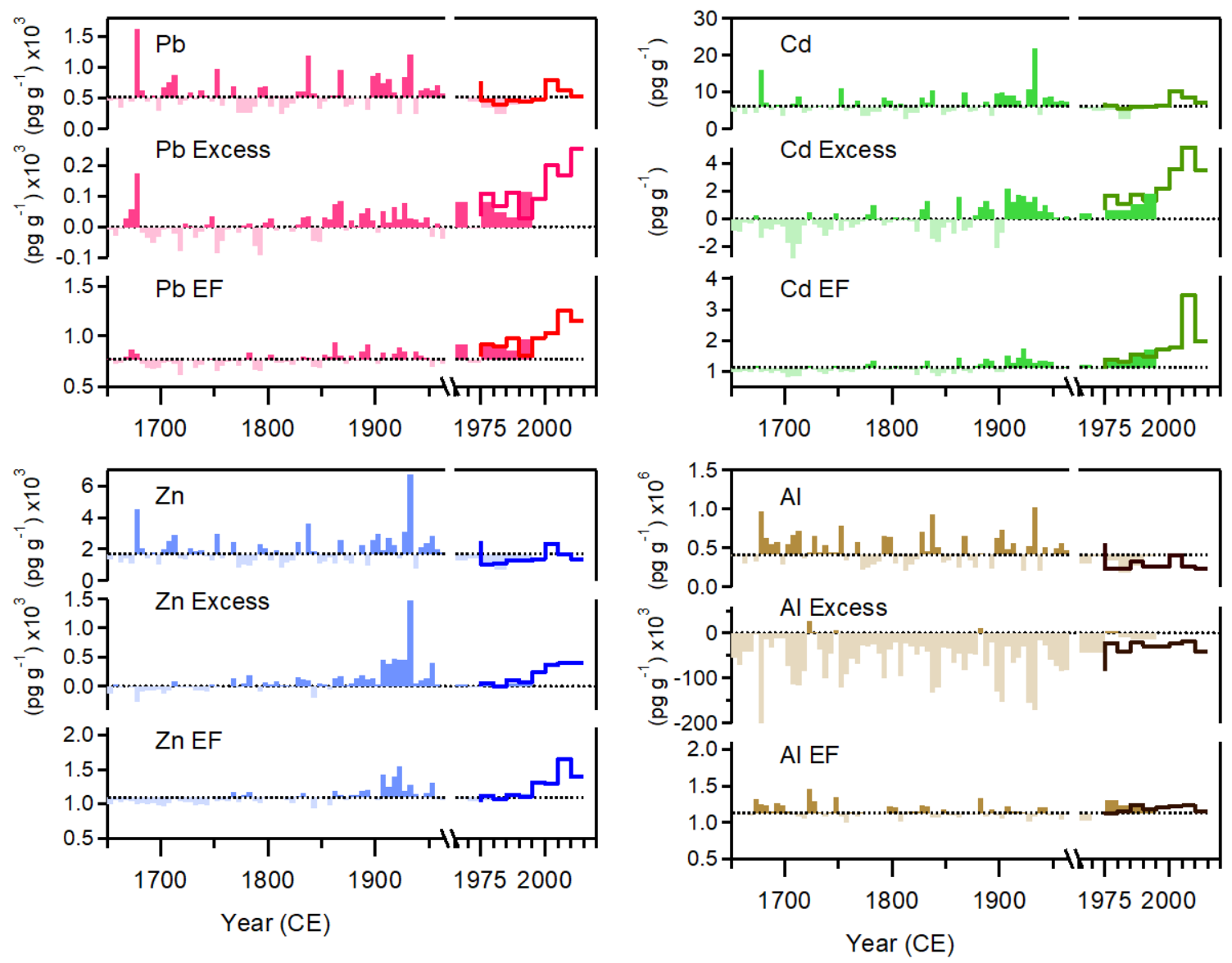

73

Figure S1. $\mathrm{Pb}, \mathrm{Cd}, \mathrm{Zn}$, and $\mathrm{Al}$ shown as 5-year median concentrations, excess concentrations and enrichment factors (EF) from the 1992 Guliya ice core (1650-1991) and the 2015 Guliya ice core (1971-2015; thick line). The horizontal dotted lines show the 1650-1991 concentration and EF medians for the 1992 core. 


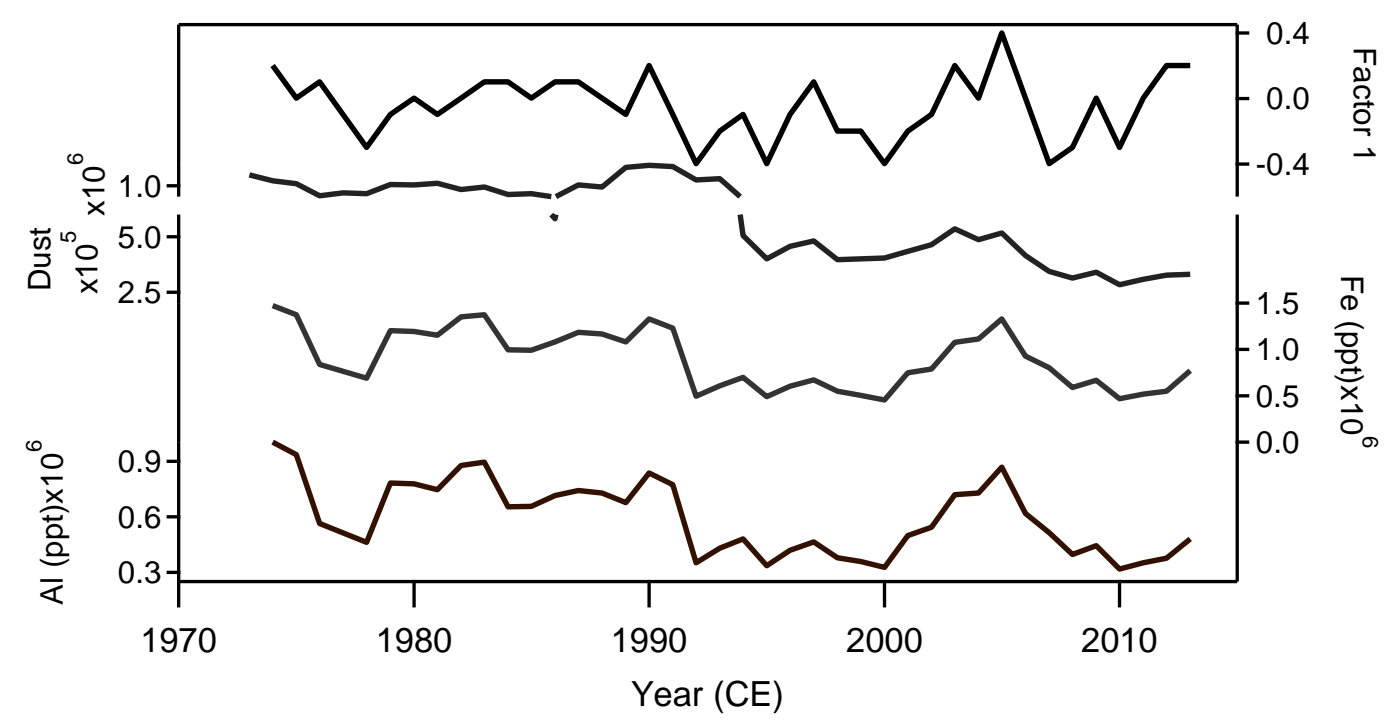

Figure S2. Comparison of Factor 1 scores (crustal contribution), dust concentrations (particles $\mathrm{ml}^{-1}$ ) (Thompson et al., 2018), and concentrations of the typical crustal TEs Fe and Al. All data are presented as five-year running 80 means.

81

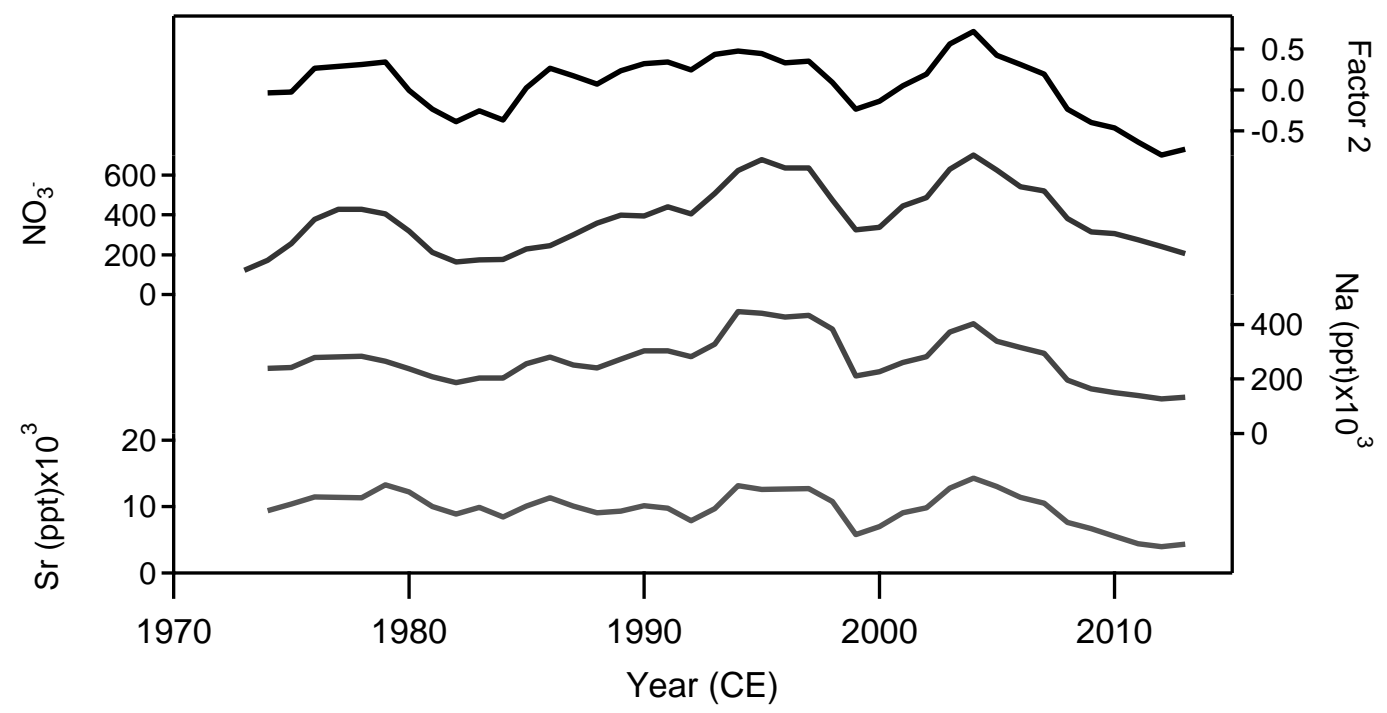

83 Figure S3. Comparison of Factor 2 scores (evaporitic contribution), $\mathrm{NO}_{3}{ }^{-}$ion concentrations (Thompson et al., 2018), and TEs concentrations of sodium (Na) and strontium (Sr). All data are presented as fiveyear running means. 


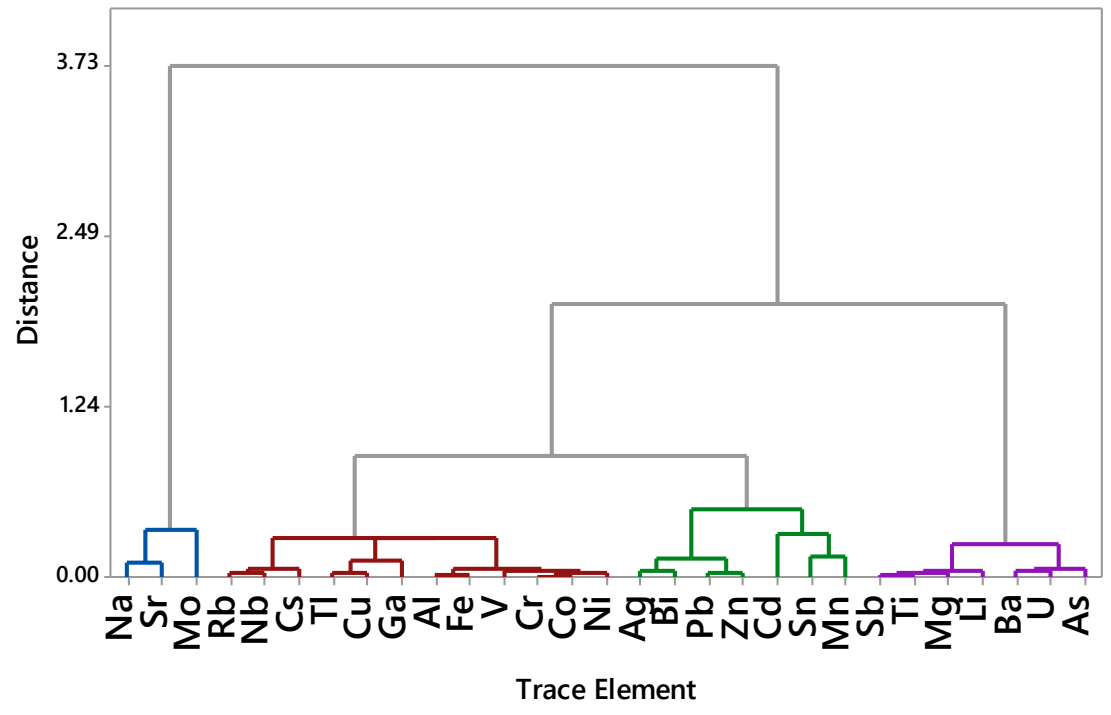

88 Figure S4. Cluster analysis extracted from the first three factors during the 1971-2015 period.

89

90

91

92

93 
(a) Metal production

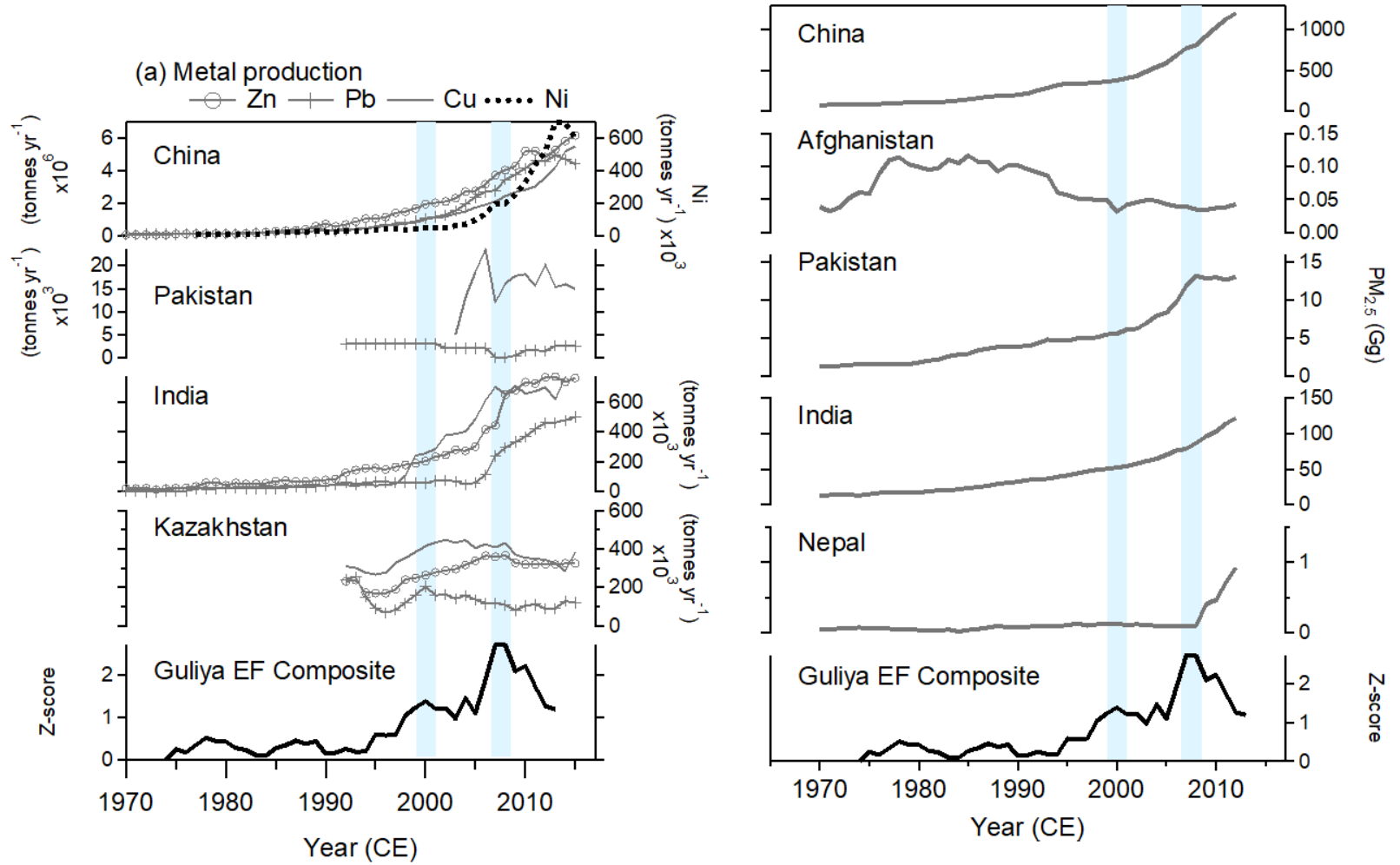

(b) $\mathrm{PM}_{2.5}$ Industrial processes

95 Figure S5. (a) Metal production in China ( $\mathrm{Zn}, \mathrm{Pb}, \mathrm{Cu}$, and $\mathrm{Ni})$, Pakistan $(\mathrm{Pb}, \mathrm{Cu}), \mathrm{India}(\mathrm{Zn}, \mathrm{Pb}, \mathrm{Cu})$ and

96 Kazakhstan ( $\mathrm{Zn}, \mathrm{Pb}, \mathrm{Cu})(\mathrm{BGS}, 2015)$ and (b) $\mathrm{PM}_{2.5}$ from industrial processes (including the production of cement,

97 lime, chemicals, and metal production). The Guliya EF composite (average of $\mathrm{Cd}, \mathrm{Pb}, \mathrm{Zn}$, and Ni EF z-scores) is

98 shown at the bottom of each panel for comparison. The two Guliya maxima at 2000 and 2008 are shown as shaded 99 bars. 
(a) Phosphate fertilizer

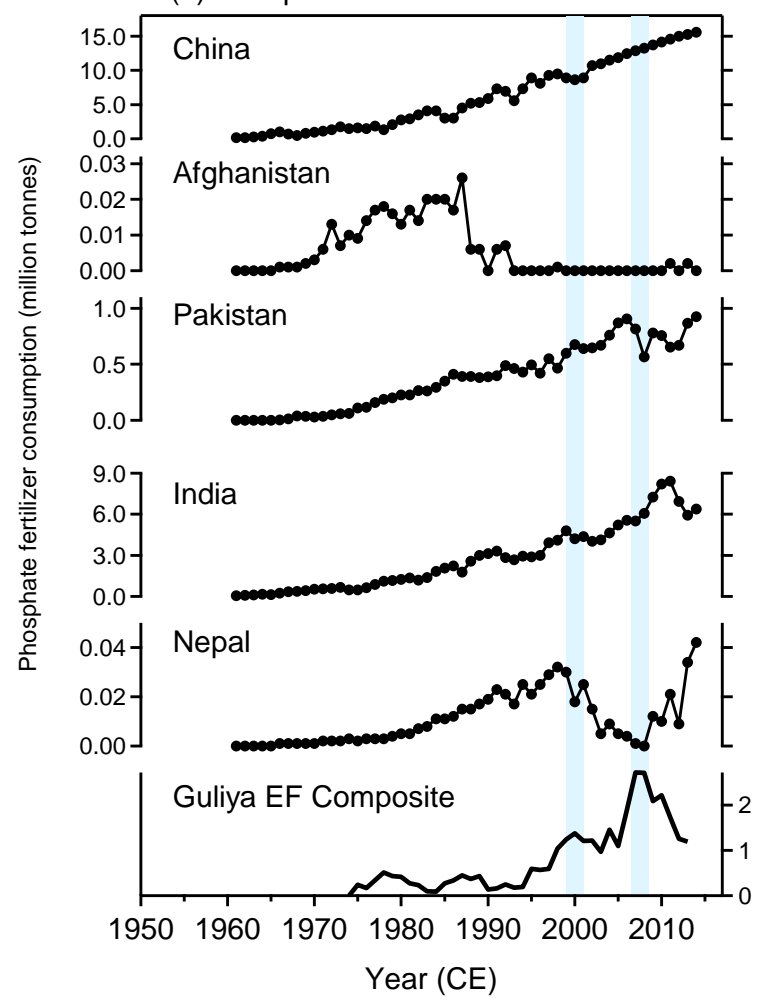

(b) $\mathrm{PM}_{2.5}$ Agricultural activities

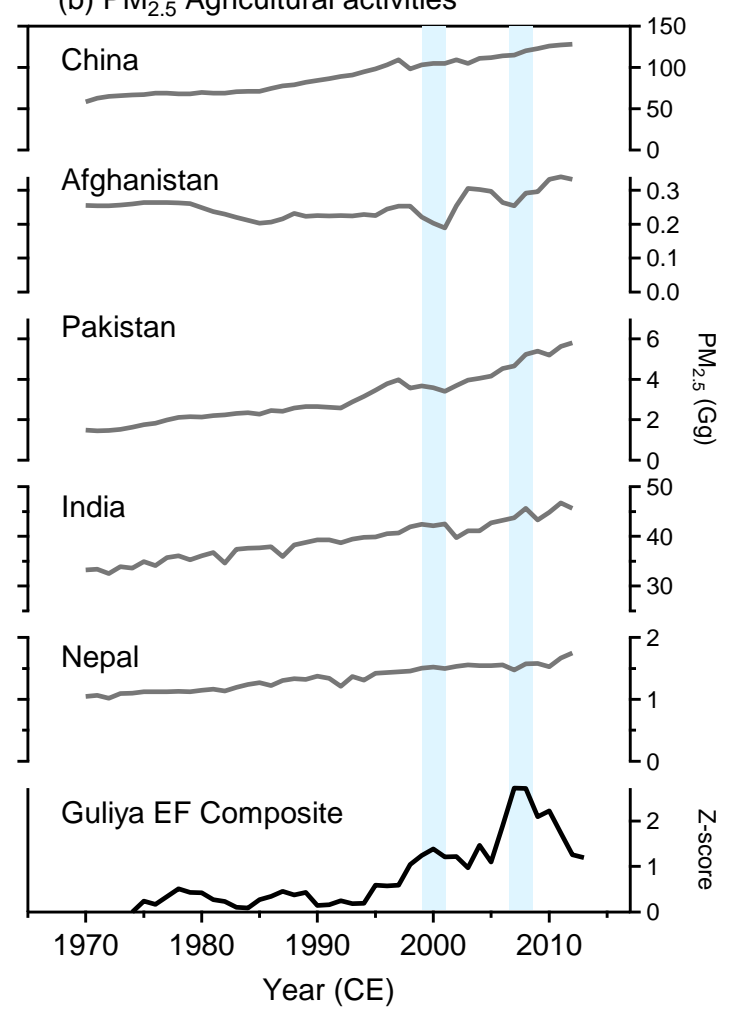

100

101

102

103

104

Figure S6. (a) Phosphate fertilizer consumption (FAO, 2019) and (b) $\mathrm{PM}_{2.5}$ from agricultural activities (including direct soil emission, rice cultivation, and manure management) (EDGARv4.3.2, 2017; Crippa et al., 2018). The Guliya EF composite (average of $\mathrm{Cd}, \mathrm{Pb}, \mathrm{Zn}$, and $\mathrm{Ni}$ EF z-scores) is shown at the bottom of each panel for comparison. The two Guliya maxima at 2000 and 2008 are shown as shaded bars.

\section{References}

BGS, British Geological Survey. World Mineral Statistics and World Mineral Production, 2/1/2018, 2015.

Crippa, M., D. Guizzardi, M. Muntean, E. Schaaf, F. Dentener, J. A. van Aardenne, S. Monni, U. Doering, J. G. J. Olivier, V. Pagliari and G. Janssens-Maenhout, Gridded emissions of air pollutants for the period 1970-2012 within EDGAR v4.3.2. Earth Syst. Sci. Data, 10, 1987-2013, 10.5194/essd-10-1987-2018, 2018.

EDGARv4.3.2, European Commission, Joint Research Centre (EC-JRC)/Netherlands Environmental Assessment Agency (PBL). Emissions Database for Global Atmospheric Research (EDGAR), release EDGAR v4.3.2 (1970 2012), 2017.

FAO, Food and Agricultural Organization of the United Nations . Phosphate Fertilizer Consumption, 4/22/2019, 2019.

Thompson, L. G., T. Yao, M. E. Davis, E. Mosley-Thompson, G. Wu, S. E. Porter, B. Xu, P.-N. Lin, N. Wang, E. Beaudon, K. Duan, M. R. Sierra-Hernández and D. V. Kenny, Ice core records of climate variability on the Third Pole with emphasis on the Guliya ice cap, western Kunlun Mountains. Quat. Sci. Rev., 188, 1-14, 2018. 